\title{
Status Mutu Air Sungai Unda Pada Lahan Eks Galian C Kabupaten Klungkung
}

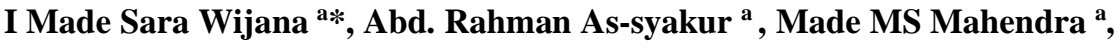 \\ I GA Kunti Sri Panca Dewi ${ }^{\text {a }}$ \\ ${ }^{a}$ Departemen Riset Lingkungan Hidup Universitas Udayana, Denpasar, Bali-Indonesia \\ *Email: sarawijana@unud.ic.id
}

Diterima (received) 8 Januari 2020; disetujui (accepted) 30 Juni 2020; tersedia secara online (available online) 1 Agustus 2020

\begin{abstract}
The Unda River (Tukad) is the second largest river in Bali Province after the Ayung River. The Unda River has been used for various activities, such as tourism activities for white water rafting and agricultural irrigation activities. In addition, Unda River water is planned to be used as a raw water source in the planned construction of the Bali Cultural Center (PKB) which is planned to be built in the lower reaches of the Unda River. Therefore, it is necessary to conduct research related to the water quality of the Unda River, especially in the Lower Unda River. Water quality analysis refers to class II water quality standards according to the Bali Governor Regulation Number 16 of 2016. Meanwhile, the analysis of water quality status uses the pollution index (IP) according to the Decree of the Minister of the Environment Number 115 of 2003. The results of the analysis show that water quality parameters that exceed the highest quality standard is downstream (sampling point 3 ) with 4 (four) parameters, namely Total Dissolved Solid (TDS), chemical oxygen demand (COD), total coliform and fecal coli. While the sampling points 1 (one) and 2 (two), the parameters that exceed the quality standard are total coliform and fecal coli. In addition, the results of this study also show that the pollution index value downstream is increasing, where at sampling point 1 which is a DAM location has a pollutant index of 3.78 (light pollution) and at sampling point 2 of 6.27 (moderate pollution) and at sampling point 3 of 7.67 (medium polluted).
\end{abstract}

Keywords: Unda river; water quality; Coliform; pollution index

\begin{abstract}
Abstrak
Sungai (Tukad) Unda merupakan sungai terbesar ke-dua di Provinsi Bali setelah Sungai Ayung. Sungai Unda selama ini telah digunakan untuk berbagai aktifitas, seperti aktifitas pariwisata untuk arung jeram serta aktivitas pengairan pertanian. Selain itu, Air Sungai Unda rencananya akan digunakan sebagai sumber air baku pada rencana pembangunan Pusat Kebudayaan Bali (PKB) yang rencananya akan di bangun di bagian hilir Sungai Unda. Oleh karena itu perlu dilakukan penelitian terkait dengan kualitas air sungai Unda Bagian Hilir. Analisis kualitas air mengacu baku mutu air kelas II menurut Peraturan Gubernur Bali Nomor 16 Tahun 2016. Sementara itu, analisis status mutu air menggunakan indeks pencemaran (IP) menurut Keputusan Menteri Lingkungan Hidup Nomor 115 Tahun 2003. Hasil analisis menunjukkan bahwa parameter kualitas air yang melebihi baku mutu paling banyak pada bagian hilir (titik sampling 3) dengan 4 (empat) parameter yaitu Total Dissolved Solid (TDS), kebutuhan oksigen kimia (COD), total coliform dan fecal coli. Sedangkan bagian titik sampling 1 (satu) dan 2 (dua), parameter yang melebihi baku mutu adalah total coliform dan fecal coli. Selain itu hasil penelitian ini juga menunjukkan bahwa nilai indeks pencemaran ke arah hilir semakin meningkat, dimana di titik sampling 1 yang merupakan wilayah DAM memiliki indeks pencemar 3,78 (Cemar ringan) dan di titik sampling 2 sebesar 6,27 (Cemar sedang) serta di titik sampling 3 sebesar 7,67 (Cemar sedang).
\end{abstract}

Kata Kunci: Sungai Unda; kualitas air; Coliform; indeks pencemaran

doi: https://doi.org/10.24843/blje.2020.v20.i02.p02

(C) 2019 by the authors; Content from this work may be used under the terms of the Creative Commons Attribution 3.0 licence. Any further distribution of this work must maintain attribution to the author(s) and the title of the work, journal citation and DOI. Published under licence by Udayana University, Indonesia. 


\section{Pendahuluan}

Sungai (Tukad) Unda adalah salah satu sungai yang mengalir sepanjang tahun, memiliki peran penting dalam daur hidrologi dan berfungsi sebagai daerah tangkapan air bagi daerah sekitarnya. Odum (1998) memasukkan sungai sebagai ekosistem terbuka, karena mendapat masukan dari daerah di sepanjang alirannya. Daerah Aliran Sungai (DAS) Unda memiliki luas 23337,72 Ha dan merupakan DAS terluas ke dua di Bali setelah DAS Ayung. Secara administratif, aliran sungai Unda bagian hulu sampai tengahnya berada di Kabupaten Karangasem dan bagian tengah sampai hilirinya berada di Kabupaten Klungkung. Aliran air sungai Unda bagian hulu sebagian telah dimanfaatkan untuk air baku dan bagian tengah dimanfaatkan untuk kepentingan pariwisata (arung jeram) dan irigasi pertanian. Bagian hilir setelah bendungan yang meliputi lahan seluas 289,40 hektar sebelum tahun 2002 sebagai lahan galian golongan C. Lahan tersebut berada di tiga meliputi: Desa Gunaksa, Desa Jumpai dan Desa Tangkas. Eksploitasi pasir pada lahan tersebut yang dilakukan oleh aktivitas penambangan yang tidak terkendali dan terkontrol menyebabkan terjadinya kerusakan lingkungan. Akibatnya terjadi kubangan-kubangan besar dengan kedalaman sepuluh sampai lima belas meter yang dapat membahayakan keselamatan masyarakat. Atas dasar kerusakan yang terjadi, Pemerintah Kabupaten Klungkung mengambil kebijakan untuk menghentikan kegiatan galian golongan $\mathrm{C}$ tersebut dengan diterbitkannya instruksi Bupati Klungkung Nomor 3 Tahun 2002 yang menyatakan secara tegas penghentian secara total segala aktivitas penambangan di lokasi tersebut. Sejak tahun 2002 lahan tersebut menjadi lahan yang tidak produktif lagi, yang sebelumnya sebagai sumber Pendapatan Asli Daerah (PAD) Kabupaten Klungkung dan pendapatan masyarakat.

PAD sangat penting untuk sumber pembiayaan pembangunan dan pendapatan masyarakat berkaitan dengan kesejahteraan masyarakat. Untuk pemerataan pembangunan secara wilayah dan optimalisasi produktivitas lahan, pemerintah Provinsi Bali berencana akan membangun berbagai fasilitas pada lahan tersebut, yang meliputi: pusat kebudayaan secara terpadu dengan berbagai fasilitas komersial seperti akomodasi, restoran, marina, kegiatan olah raga dan sebagainya. Pembangunan dan operasional kegiatan ini akan memerlukan air bersih dan akan menghasilkan limbah yang akan berpengaruh terhadap kualitas air sungai, khususnya air Sungai Unda di bagian hilir sebagai komponen lingkungan yang berpotensi terdampak dari rencana usaha dan/atau kegiatan tersebut. Sebagai komponen lingkungan yang berpotensi terdampak, maka kualitas lingkungan khususnya kualitas air sungai Unda di bagian hilir perlu diketahui sebelum kegiatan dilaksanakan melalui studi kualitas air sungai Unda Bagian Hilir.

\section{Metode Penelitian}

\subsection{Lokasi Penelitian dan Titik Sampling}

Bagian hilir Sungai Unda merupakan lokasi penelitian yang secara administratif berada di empat desa, yaitu Desa Tangkas, Desa Jumpai, Desa Gunaksa dan Sampalan Kelod yang termasuk ke dalam dua kecamatan yaitu Kecamatan Dawan dan Kecamatan Klungkung, Kabupaten Klungkung Provinsi Bali. Pengambilan sampel dengan metode purposive sampling pada tiga titik, yaitu:

a. Titik 1: Dam Sungai Unda Klungkung (koordinat : $-8,533861^{\circ} \mathrm{LS} ; 115,411403^{\circ} \mathrm{BT}$ )

b. Titik 2: Aliran Sungai Unda di bawah jembatan Jalan Ida Bagus Mantra (Koordinat: $-8,560776^{\circ} \mathrm{LS}$; $115.429232^{\circ} \mathrm{BT}$ )

c. Titik 3 : bagian akhir aliran sungai Unda (Koordinat: $-8.572308^{\circ} \mathrm{LS} ; 115.434204^{\circ} \mathrm{BT}$ ) 


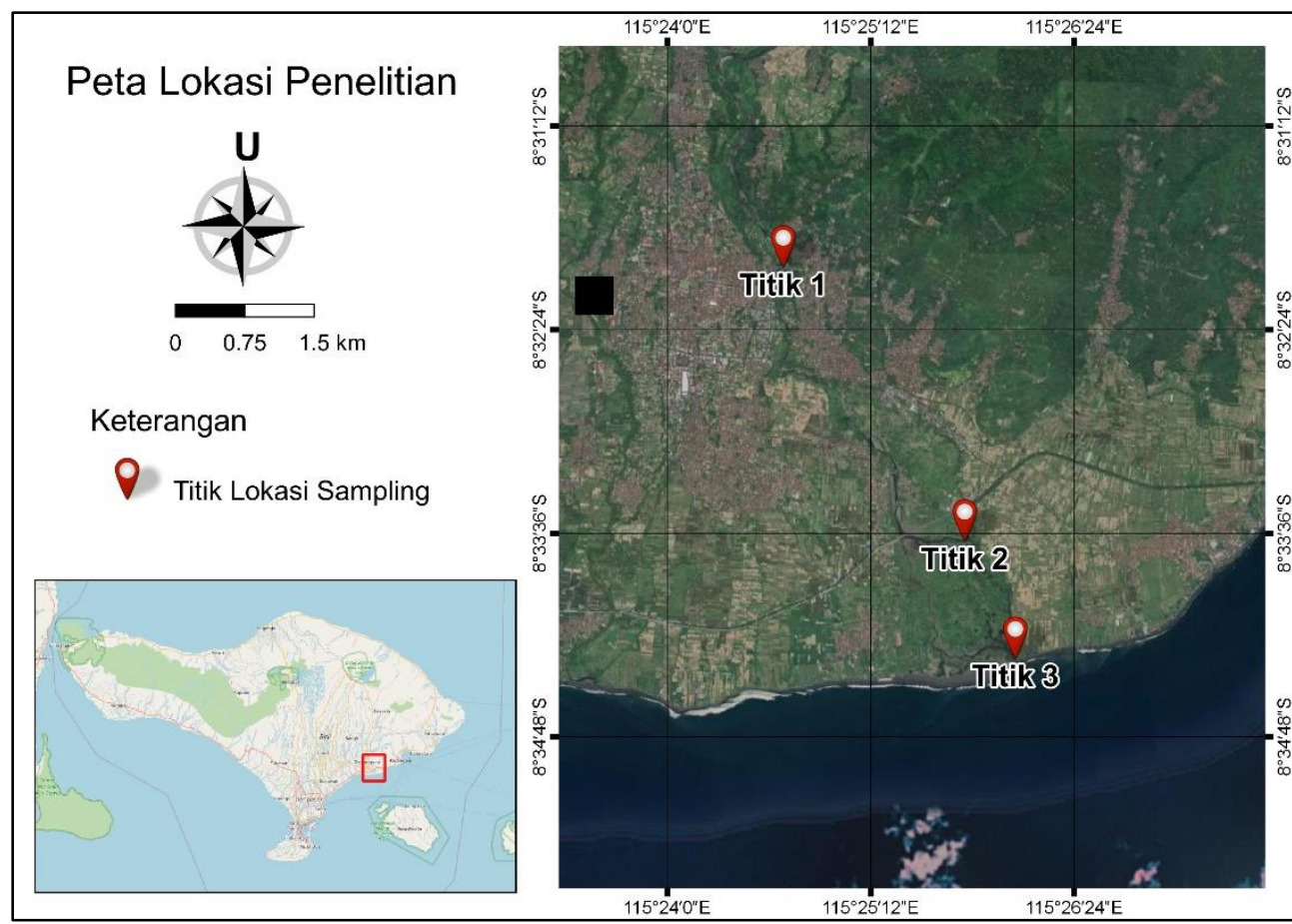

Gambar 1. Peta Lokasi Sampling

\subsection{Jumlah sampel, parameter, metode uji dan metode analisis data}

Sampling dilakukan sekali pada bulan Agustus 2020 secara purposive pada tiga titik. Parameter yang diuji terdiri atas 1 (satu) parameter fisika, sebelas (11) parameter kimia dan 2 (dua) parameter biologi. Jenis parameter dan metode ujinya serta baku mutu disajikan pada Tabel 1.Semua gambar dan tabel harus di kutip dalam uraian teks naskah, seperti "di tampilkan pada Gambar 1" atau "tersaji secara lengkap pada Tabel 1".

Tabel 1. Parameter, metode pengujian dan baku mutu

\begin{tabular}{|c|c|c|c|c|}
\hline No & Parameter & Metode & Satuan & $\begin{array}{l}\text { Baku mutu air kelas II (Peraturan } \\
\text { Gubernur Bali No. 16 Tahun 2016) }\end{array}$ \\
\hline 1 & TDS & Elektrometri & $\mathrm{mg} / \mathrm{L}$ & 1000 \\
\hline 2 & $\mathrm{pH}$ & Elektrometri & - & $6-9$ \\
\hline 3 & Nitrit $\left(\mathrm{NO}_{2}-\mathrm{N}\right)$ & Sulfanilat & $\mathrm{mg} / \mathrm{L}$ & 0,06 \\
\hline 4 & Nitrat $\left(\mathrm{NO}_{3}-\mathrm{N}\right)$ & Brucine & $\mathrm{mg} / \mathrm{L}$ & 10 \\
\hline 5 & $\mathrm{BOD}_{5}$ & Titrimetri & $\mathrm{mg} / \mathrm{L}$ & 3 \\
\hline 6 & COD & Titrimetri & $\mathrm{mg} / \mathrm{L}$ & 25 \\
\hline 7 & Minyak dan Lemak & Gravimetri & $\mathrm{mg} / \mathrm{L}$ & 1 \\
\hline 8 & Detergen & Metilen Blue & $\mathrm{mg} / \mathrm{L}$ & 0,200 \\
\hline 9 & DO & Elektrometri & $\mathrm{mg} / \mathrm{L}$ & 4 \\
\hline 10 & Total Phospat sbg $\mathrm{P}$ & Amm-Molybdat & $\mathrm{mg} / \mathrm{L}$ & 0,2 \\
\hline 11 & Sulfat & Turbidimetri & $\mathrm{mg} / \mathrm{L}$ & - \\
\hline 12 & Total Coliform & $\begin{array}{l}\text { Metode Most Portable } \\
\text { Number (MPN) }\end{array}$ & $\mathrm{Sel} / 100 \mathrm{~mL}$ & 5.000 \\
\hline 13 & Fecal coli & MPN & $\mathrm{Sel} / 100 \mathrm{~mL}$ & 1.000 \\
\hline
\end{tabular}


Analisis kualitas air mengacu baku mutu air kelas II menurut Peraturan Gubernur Bali Nomor 16 Tahun 2016). Analisis status mutu air menggunakan indeks pencemaran (IP) menurut Keputusan Menteri Lingkungan Hidup Nomor 115 Tahun 2003, dengan persamaan sebagai berikut.

$$
\mathrm{PI}_{\mathrm{j}}=\sqrt{\frac{\left(\mathrm{C}_{\mathrm{i}} / \mathrm{L}_{\mathrm{ij}}\right)_{\mathrm{M}}^{2}+\left(\mathrm{C}_{\mathrm{i}} / \mathrm{L}_{\mathrm{ij}}\right)_{\mathrm{R}}^{2}}{2}}
$$

$\mathrm{PI}_{\mathrm{j}}$ adalah Indeks pencemaran bagi peruntukan $\mathrm{j}, \mathrm{C}_{\mathrm{i}}$ menyatakan konsentrasi parameter kualitas air (i), $\mathrm{L}_{\mathrm{ij}}$ adalah konsentrasi parameter kualitas air (i) yang tercantum dalam baku peruntukan air (j), sementara $\mathrm{M}=$ maksimum, $\mathrm{R}=$ rerata. Kriteria evaluasi nilai $\mathrm{PI}_{\mathrm{j}}$ adalah $0 \leq \mathrm{PI}_{\mathrm{j}} \leq 1,0$ adalah kondisi baik (good) $; 1,0<\mathrm{PI}_{\mathrm{j}} \leq 5,0$ cemar ringan (slightly polluted); 5,0< $\mathrm{PI}_{\mathrm{j}} \leq 10$ cemar sedang (fairly polluted), $\mathrm{PI}_{\mathrm{j}}$ $>10,0$ dengan status perairan cemar berat (heavily polluted).

\section{Hasil dan Pembahasan}

Hasil pemeriksaan parameter kualitas air sampel disajikan pada tabel 2. Hasil analisis nilai indeks pencemaran dan status mutu air disajikan pada tabel 3 .

Tabel 2. Hasil Pemeriksaan Parameter Kualitas Air

\begin{tabular}{clccccc}
\hline \multirow{2}{*}{ No } & \multirow{2}{*}{ Parameter } & Satuan & \multirow{2}{*}{$\begin{array}{c}\text { Baku mutu } \\
\text { air kelas II }\end{array}$} & $\begin{array}{c}\text { Titik } \\
\text { sampling 1 }\end{array}$ & $\begin{array}{c}\text { Titik } \\
\text { sampling 2 }\end{array}$ & $\begin{array}{c}\text { Titik } \\
\text { sampling 3 }\end{array}$ \\
\hline 1 & TDS & $\mathrm{mg} / \mathrm{L}$ & 1000 & 191,4 & 194 & $\mathbf{4 . 0 8 4 *}$ \\
2 & $\mathrm{pH}$ & - & $6-9$ & 8,44 & 8,63 & 7,92 \\
3 & Nitrit $\left(\mathrm{NO}_{2}-\mathrm{N}\right)$ & $\mathrm{mg} / \mathrm{L}$ & 0,06 & 0,004 & 0,003 & 0,005 \\
4 & Nitrat $\left(\mathrm{NO}_{3}-\mathrm{N}\right)$ & $\mathrm{mg} / \mathrm{L}$ & 10 & 0,87 & 0,85 & 0,89 \\
5 & BOD & $\mathrm{mg} / \mathrm{L}$ & 3 & 1,24 & 1,85 & 1,04 \\
6 & COD & $\mathrm{mg} / \mathrm{L}$ & 25 & 8,0 & 13,0 & $27,0^{*}$ \\
7 & Minyak dan Lemak & $\mathrm{mg} / \mathrm{L}$ & 1 & $<0,1$ & $<0,1$ & $<0,1$ \\
8 & Detergen & $\mathrm{mg} / \mathrm{L}$ & 0,200 & $<0,05$ & $<0,05$ & $<0,05$ \\
9 & DO & $\mathrm{mg} / \mathrm{L}$ & 4 & 7,92 & 8,46 & 7,84 \\
10 & Total Phospat sbg P & $\mathrm{mg} / \mathrm{L}$ & 0,2 & 0,065 & $<0,01$ & $<0,01$ \\
11 & Sulfat & $\mathrm{mg} / \mathrm{L}$ & - & 52,572 & 50,749 & 268,40 \\
12 & Total Coliform & $\mathrm{Sel} / 100 \mathrm{~mL}$ & 5.000 & $11.000^{*}$ & $35.000^{*}$ & $540.000^{*}$ \\
13 & Fecal coli & $\mathrm{Sel} / 100 \mathrm{~mL}$ & 1.000 & $7.000^{*}$ & $35.000^{*}$ & $110.000^{*}$ \\
\hline
\end{tabular}

Keterangan : * melebihi baku mutu

Tabel 2 di atas menunjukkan, bahwa parameter kualitas air yang melebihi baku mutu paling banyak pada bagian hilir (titik sampling 3) dengan 4 (empat) parameter yaitu: TDS, COD, total coliform dan fecal coli. Sedangkan bagian titik sampling 1 (satu) dan 2 (dua), parameter yang melebihi baku mutu adalah sama. Parameter tersebut adalah total coliform dan fecal coli, tetapi dengan besaran yang berbeda. Kandungan total coliform pada titik sampling 2 (dua), sebesar $35.000 \mathrm{Sel} / 100 \mathrm{~mL}$ tiga kali lebih besar dari kandungan total coliform pada titik sampling 1 (satu). Demikian juga halnya dengan kandungan fecal coli pada titik sampling 2 (dua) lima kali lebih besar dari pada kandungan fecal coli pada titik sampling 1 (satu). Tingginya kandungan TDS pada titik sampling 3 (tiga) atau bagian hilir/dekat muara, karena air pada titik ini dipengaruhi oleh air laut. TDS menggambarkan padatan terlarut atau konsentrasi jumlah ion di dalam air. Kandungan TDS umumnya dalam bentuk garam anorganik. Kandungan garam (natrium klorida) yang terkandung dalam air laut merupakan zat atau senyawa yang berpengaruh terhadap kandungan TDS air (Effendi, 2003). Hal ini terjadi pada saat air laut pasang akan terjadi pencampuran air sungai dan air laut. Air laut memiliki kandungan TDS sangat tinggi, kadar TDS air laut di Teluk Lada Perairan Selat Sunda 26.329 ppm (Komala., dkk, 2011), TDS air laut teluk Youtefa adalah 34.400 ppm 
(Erari, 2012). Selain itu TDS perairan sangat dipengaruhi oleh pelapukan batuan, limpasan dan pengaruh antropogenik berupa limbah domestik dan industri).

Tabel 3. Nilai Indeks Pencemaran dan Status Mutu Air

\begin{tabular}{ccc}
\hline Titik sampling & Nilai Indeks Pencemaran & Status Mutu Air \\
\hline 1 & 3,78 & Cemar ringan \\
2 & 6,27 & Cemar sedang \\
3 & 7,67 & Cemar sedang \\
\hline
\end{tabular}

Tabel 3 di atas menunjukkan, nilai indeks pencemaran ke arah hilir semakin meningkat. Nilai indeks pencemaran berhubungan dengan besaran nilai parameter dan baku mutu. Baku mutu yang digunakan sebagai pembanding adalah air Kelas II (Peraturan Gubernur Bali No. 16 Tahun 2016 tentang Baku Mutu Lingkungan dan Kriteria Baku Kerusakan Lingkungan Hidup. Mengacu kepada kriteria evaluasi nilai indeks pencemaran, status mutu air pada titik 1 (satu) adalah tercemar ringan dan titik 2 (dua) dan 3 (tiga) dengan status tercemar sedang. Parameter penentu status adalah total coliform dan fecal colli. Kandungan total coliform 2,2 kali lebih tinggi dari baku mutu pada titik satu, tujuh kali pada titik 2 dan 108 kali pada titik tiga. Kandungan fecal coli 7 kali lebih tinggi dibanding dengan baku mutu pada titik 1 (satu), 35 kali pada titik dua dan 110 kali pada titik 3 (tiga). Disamping adanya faktor akumulasi ke arah hilir juga dipengaruhi semakin banyaknya kegiatan di sekitar lokasi sebagai penyumbang terhadap kandungan total coliform dan fecal coli. Terdapat hubungan antara penggunaan lahan dengan konsentrasi bakteri pada sungai (Eleria dan Vogel, 2005). Kegiatan di daerah bantaran Sungai Unda khususnya di eks galian C Gunaksa seperti kegiatan penggembalaan sapi yang fesesnya dapat langsung maupun tidak langsung berkontribusi terhadap ke dua parameter ini, pembuangan air limbah ternak babi baik langsung maupun tidak langsung dapat berpengaruh, dan terdapat kegiatan permukiman semi permanen. Mengangkatnya aliran permukaan akibat adanya hujan akan berpengaruh terhadap peningkatan fecal coli dalam perairan sungai (Kalaivani, et al., 2014). Kelompok bakteri fecal coli terdapat jenis bakteri patogen antara lain: Escherichia coli, Shigella sp., Vibrio cholera dan Salmonella sp.

\section{Simpulan}

Mengacu pada hasil dan pembahasan di atas dapat disimpulkan, status mutu air sungai Unda yang berada pada lahan eks galian $\mathrm{C}$ gunaksa adalah tercemar ringan dan sedang. Parameter penentu status adalah kandungan total coliform dan fecal coli. Penyebab tingginya kandungan total coliform dan fecal coli berhubungan dengan kegiatan di daerah bantaran sungai pada lahan eks galian C Gunaksa.

\section{Daftar Pustaka}

Effendi, H., 2003, Telaah Kualitas Air Bagi Pengelolaan Sumber Daya dan Lingkungan, Kanisius: Yogyakarta, 98 hal

Eleria, A. \& Vogel, W.M. (2005). Predicting Fecal Coliform Bacteria Levels in the Charles River, Massachusetts, USA. Journal of the American Water Resources Association (JAWRA), 41(5), 11951209.

Erari, S.S., Mangimbulude, J, dan Lewerissa, K, 2012, Pencemaran Organik di Perairan Pesisir Pantai Teluk Youtefa Kota Jayapura Papua, Prosiding Seminar Nasional Kimia Unesa, C-327-C-340.

Kalaivani, T.R., Dheenadayalan, M.S. \& Sivakumar, K.K. (2014). Microbial Status in River Coom Pollution, Chennai, India. Journal of Science, 4(2), 113-116.

Komala, R.F., Yulianda, Lumbanbatu, D.T.F., dan Setyobudiandi, I., 2011, Indeks Kondisi Kerang Darah (Anadaragranosa) Sebagai Indikator Kualitas Lingkungan di Teluk Lada Perairan Selat Sunda, Bioma, Jurnal Jurusan Biologi, FMIPA, Universitas Negeri Jakarta, 9(2), 8-12. 
Jurnal Bumi Lestari |Vol. 20, No. 02| 12-17 (2020)

Odum, E. P. 1998. Dasar-dasar Ekologi. Diterjemahkan dari Fundamental of Ecology oleh T. Samingan. Gadjah Mada University Press. Yogyakarta. 